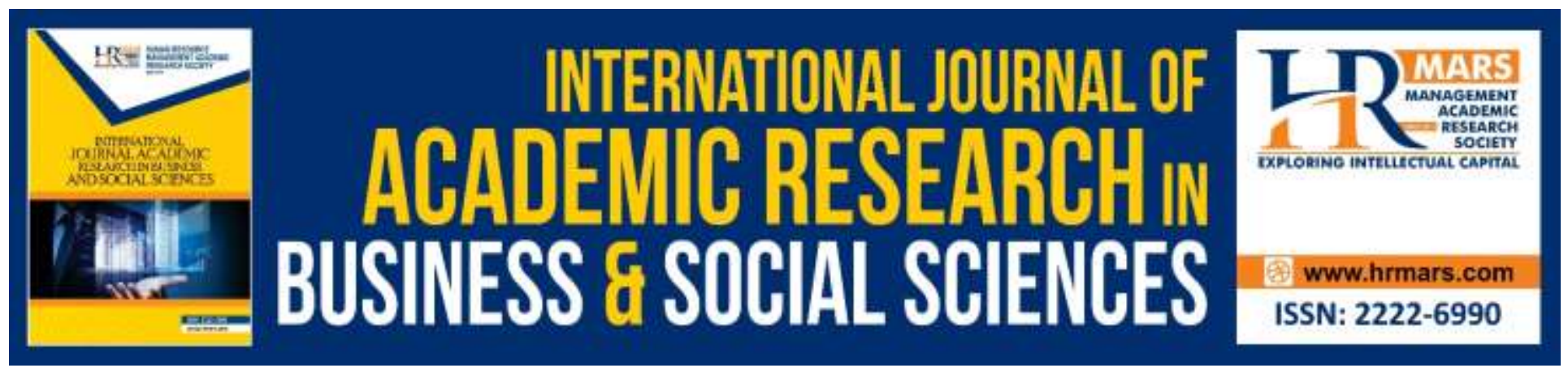

\title{
The Use of Dictocomp Technique to Improve Text Structure in Writing of Recounts among Year 4 Intermediate Proficiency Pupils
}

Malket Singh, Azlina Abdul Aziz

To Link this Article: http://dx.doi.org/10.6007/IJARBSS/v10-i6/7334

DOI:10.6007/IJARBSS/v10-i6/7334

Received: 25 April 2020, Revised: 27 May 2020, Accepted: 05 June 2020

Published Online: 30 June 2020

In-Text Citation: (Singh \& Aziz, 2020)

To Cite this Article: Singh, M., \& Aziz, A. A. (2020). The Use of Dictocomp Technique to Improve Text Structure in Writing of Recounts among Year 4 Intermediate Proficiency Pupils. International Journal of Academic

Research in Business and Social Science, 10(6), 586-594.

Copyright: (C) 2020 The Author(s)

Published by Human Resource Management Academic Research Society (www.hrmars.com)

This article is published under the Creative Commons Attribution (CC BY 4.0) license. Anyone may reproduce, distribute, translate and create derivative works of this article (for both commercial and non-commercial purposes), subject to full attribution to the original publication and authors. The full terms of this license may be seen

at: http://creativecommons.org/licences/by/4.0/legalcode

\section{Vol. 10, No. 6, 2020, Pg. 586 - 594}

Full Terms \& Conditions of access and use can be found at http://hrmars.com/index.php/pages/detail/publication-ethics 


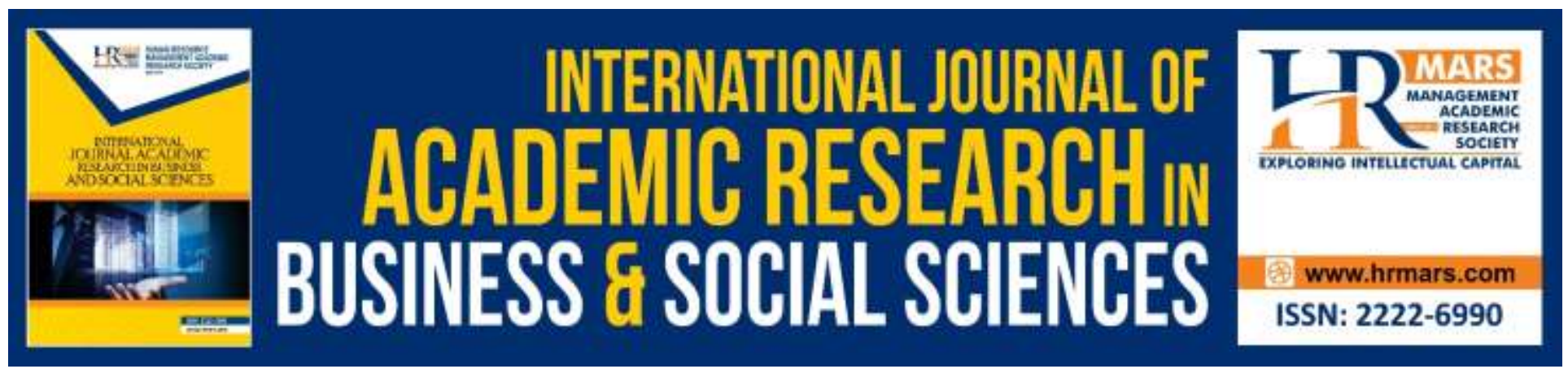

\title{
The Use of Dictocomp Technique to Improve Text Structure in Writing of Recounts among Year 4 Intermediate Proficiency Pupils
}

\author{
Malket Singh \\ Sekolah Kebangsaan Kampung Cheras Baharu, Selangor \\ Email: malketsinghbhal@gmail.com \\ Azlina Abdul Aziz \\ Centre of Innovation in Teaching \& Learning \\ Faculty of Education, Universiti Kebangsaan Malaysia, Malaysia \\ Email: azlina1@ukm.edu.my
}

\begin{abstract}
This study was sought to investigate the effectiveness of Dictocomp technique to improve text structure in writing of recounts among Year 4 pupils. The study was aimed to answer two research questions: 1) can Dictocomp technique improve text structure in pupils' writing of recounts? 2) Does the improvement in text structure in the pupils' writing lead to a better logical connection of ideas in their writing? Six pupils demonstrating weakness in text structure in the writing of recounts were selected as research participants. Four lessons were planned on the intervention in this research. They respectively comprised of four meticulously planned stages in the Dictocomp technique; preparation, dictation, reconstruction as well as analysis and correction. This study employed both the quantitative; tests, and qualitative; interviews and journal entries, data collection methods. The data for the tests was analyzed by its mean score and by comparison of individual participant's results in Test 1 and Test 2. The data for the interviews was analyzed using the Constant Comparative Method. Finally, the journal entries were reviewed for key points to triangulate the data obtained from the tests and the interviews. The results of this study demonstrated that the use of the Dictocomp technique led to a significant improvement in the text structure construct in the participants' writing of recounts. The findings further highlighted that the improvement in the text structure construct has also led to a parallel improvement in the logical connection of ideas construct in the participants' writing of recounts.
\end{abstract}

Keywords: Dictocomp, Text Structure, Writing of Recounts, Writing, English Language 


\section{Introduction}

Difficulties in writing can be devastating to a child's education and self-esteem (Raimes, 1995). This is true in the ESL context because numerous studies in the field of writing skill reported that writing is the most difficult skill to be mastered in the English language (Raimes, 1995). I found these findings to be similar with my experience during my teaching practices whereby I realized that my pupils were having difficulty in writing of recounts specifically in their text structure. Text structure plays an indispensable role in organizing the delivery of ideas in written compositions. This is so because it will endow the writer a sense of purpose, which he or she might otherwise lack Bereiter (1980) and that will, in turn, help to define reader's expectations of the order of textual information as well as its inter-relationship (Barnett, 1989). Adherence to text structure is particularly emphasized among upper primary pupils who are in the beginning level of writing compositions. Accordingly, the Dictocomp technique was employed to improve pupils' text structure in their writing of recounts. In this study, it was also assumed that the improvement in text structure in pupils writing would be interrelated with the improvement in the logical connection of ideas construct. As such, it is another area investigated in this study.

\section{Research Focus}

This study focused on using the Dictocomp technique to improve text structure in writing of recounts. According to Ministry of Education, New Zealand (2015a) a recount is a record of events. It is a type of narrative writing intended to recall an event or experience for the reader's information or enjoyment. MOE, New Zealand (2015b) further explained this type of narrative writing has an orientation which gives the background to the events that took place. It has a series of events told in the past tense. Time markers such as "yesterday", "then", "soon" are used to sequence the events (MOE New Zealand, 2015a).

The term "text structure" refers to organization of ideas (Taylor, 1982), and the logical connection among ideas, in terms of subordination and coordination of the information in the text (Armbuster, Anderson \& Ostertaq, 1987). Cali and Bowen (2014) further elaborated that text structure refers to organizational patterns or rhetorical conventions in a text, or in other words, the structure through which a writer wants to present his ideas in writing. For example, in presenting on the hazards of smoking, the writer employs a cause and effect structure whereby he presents all causes leading people to smoke followed by their effects on their health. McGee and Richgels (1985, p. 26) refer to the term as "the scheme by which the content is organized". Text structure is also specific to a particular genre writing being written (McGee \& Richgels, 1985).

The writing of recounts, in particular, employs the climactic pattern of text structure (Dymock, 2007). The climactic pattern is comprised of 5 main sub-structures. They are: 1) exposition, 2) rising action, 3) climax, 4) falling action and 5) resolution. In this pattern, items are arranged from the least important to the most important. Dymock (2007) further remarked that when writers decide on what event to retell, they most likely thought of the "climax", the high point of excitement or the turning point of the event or experience. In attempt to retell this event and to get to the climax, he added, writers will also need to include rising action (events before the climax) and falling action (events after the climax). Since, the narrative writing written by the pupils in this research is rather short, it was deemed wise to simplify and re-term the climactic pattern into three main sections: exposition (introduction), climax (body) and resolution (conclusion), for ease of understanding. 
According to Layne and Lewis (2009), the main idea (or orientation) of the recount is established in the introductory paragraph. This is where a writer provides background information. Among the information to be included in this section, in order, are time, people involved, place and reason for the account to take place which, answers 4 out 5 wh-question words; when, who, where and why, respectively. The climax (body) section, on the other hand, would include specific events or activities that took place in the account which would answer the wh-question "what". If there are more than one event or activity that took place in the account, the writer needs to order them in their chronological order (order of time) which incorporates the chronological text structure to some extent (Cali \& Bowen, 2014). In writing of recounts in this context, the resolution (conclusion) can be an expression of the writer's remark or feeling towards the event.

According to Davis and Rinvolucri (1995) Dictocomp is a technique for practicing composition. It is a guided writing that combines text dictation and text reconstruction. A short text is read at normal speed to a class of learners who jot down familiar words as they listen. At the end of the dictation stage, most learners have only a small number of isolated words (or fragments) which together make up a very incohesive, "battered text". In small groups, the pupils then pool their resources to construct their version of the original text. In the final stage, the various versions that the pupils have produced are subjected to close analysis and comparison. Through both the task of reconstruction and the following error analysis, pupils refine their understanding of writing composition.

In this study, the Dictocomp technique was adapted to suit the participants' proficiency level. The adaptation, in particular, was done at the dictation stage whereby a note-taking strategy for the pupils to write the content words effectively, was employed. This note-taking strategy was used in the form of a worksheet. It comprised of five columns, each labelled as: "When?", "Who?", "Where?", "Why?" and "Why?", organized in an I-think map format. These five Wh-questions answers the five elements needed in the climactic pattern text structure.

\section{Research Questions}

Based on the interest of this research to use the Dictocomp technique in improving text structure in writing of recounts, the following research questions are raised.

\section{Can Dictocomp technique improve text structure in pupils' writing of recounts?}

2. Does the improvement in text structure in the pupils' writing lead to a better logical connection of ideas in their writing?

\section{Research Participants}

Six Year 4 intermediate proficiency pupils were selected as participants based on their weak performance in their writing skill particularly on text structure demonstrated during the lessons. As such, the selection of the participants were done by means of purposive sampling as it will provide the best information in this research (Stringer, 2007). 


\section{Action Taken}

\section{Intervention}

The intervention was carried out in four lessons and all the lessons were executed in one week. The lessons were similar in their steps and procedure except for their topic which were aligned with the Yearly Scheme of Work. The topics that the lesson were based on were; "Unit 6: Care for the Sea", "Unit 7: Blogging", "Unit 8: The Prince and the Thieves" and "Unit 9: Our Solar System". Each of the lessons was comprised of 4 main stages of the Dictocomp technique. They were preparation, dictation, reconstruction, analysis and correction. The preparation stage involved a set induction, teaching of difficult vocabularies and management of the pupils into groups. Next, the dictation stage comprised of listening to the dictation text and jotting down of relevant content words, individually, into the note-taking worksheet given to the participants. These words were discussed by the participants in their respective groups to reconstruct the text dictated to them. Finally, in the analysis and correction stage, their answers were compared against the actual transcript of the dictated text.

\section{Data Collection and Analysis Methods}

Both quantitative and qualitative data collection methods are employed in this study. The quantitative data collection method is employed through the use of tests while qualitative data collection methods are employed through the use of both participants' interview and my daily journal entries. The tests comprised of Test 1 and Test 2 which were respectively, executed before and after the intervention lessons. The interview was semi structured in nature and was carried out after Test 2. Finally, journals were written throughout the intervention process. Three data collection methods were also selected to ensure triangulation of results in this research.

Test 1 and Test 2 was analysed by means of its mean score. Individual score of the participants in both Test 1 and Test 2 was also compared. The findings by the tests were substantiated by the interview results which were analysed thematically using the Constant Comparative Method. Finally, the journal entries were reviewed for key points to support and triangulate the findings of the tests and interviews.

\section{Research Findings}

\section{Research Question 1}

The comparison of results obtained in Test 1 and Test 2 which demonstrate participants' compliance on the climactic text structure in their writing is presented in Table 1.

Table 1: Participants' results in Test 1 and Test 2

\begin{tabular}{cccc}
\hline Participant & Test 1 & Test 2 & Difference \\
\hline 1 & 80 & 85 & 5 \\
2 & 70 & 85 & 15 \\
3 & 65 & 85 & 20 \\
4 & 80 & 90 & 10 \\
5 & 80 & 90 & 10 \\
6 & 80 & 90 & 5 \\
\hline Mean & $\mathbf{7 5 . 8}$ & $\mathbf{8 7 . 5}$ & $\mathbf{1 1 . 7}$ \\
\hline
\end{tabular}


Table 1 shows that the mean for Test 1 and Test 2 are 75.8 and 87.5 respectively. A comparison in mean scores of both tests show that the mean score for Test 2 is higher by 11.7 percent compared to Test 1 . This indicates that the performance of the participants were generally better in Test 2 as compared to Test 1 . This is also indicated by the improvement in percentage of participants who scored an A, which is $66.6 \%$ in Test 1 and $100 \%$ in Test 2.

In analyzing the individual score of participants in both tests, it can be noted that the performance of the participants can be categorized into two categories; those who have shown a vast improvement and those who have shown a slight improvement in their text structure.

In particular, there are 2 participants who demonstrated a vast difference in their performance in both tests. These are Participant 2 and 3 who demonstrated a difference of 15 and 20 marks respectively. These 2 participants are also accounted for the $33.4 \%$ of participants who scored B in Test 1 and eventually scored an A in Test 2.

Based on the document analysis of Participant 2, it was noted that the factors leading to her improved performance in text structure were: 1) higher level of compliance to the answers of Whquestion words, 2) reduced incidence of repetition, 3) presentation of ideas in a sequential order and 4) having a concluding statement that sums up the recount. A follow up interview with Participant 2 revealed that elements that led to the improvement in her writing were put forth by two keys words in the interview: "the use of worksheet" and "show us where answers of the worksheet are put in the essay". In other words, she credited her improvement, respectively, as being a result of the notetaking strategy employed and errors analysis done on the participants work. These findings also correlated with my journal entries whereby I noted that: “...pupils were very much engrossed in looking at their peer's responses... I believe they did so because they knew how important the information answering the Wh-questions were in reconstructing the essay".

Similar improvement was also noted in Participant 6's responses where by it was noted that the factors led to his improvement in Test 2 were: 1) having a concluding statement through the use a paragraphing technique and 2) no repetition in his recount. As the participant claimed in the interview: "Teacher got show sample answer. Teacher also used 3 paragraphs", the improvement of having a concluding statement was attributed to error analysis and presentation of model recount at the end of the lessons. Besides, no repetition of information in his recount was indicated by my journal entry: "I noticed this particular pupil was slashing key points provided to guide him during the test... As I briefly asked him where he learned it from, he told it from my lessons". As my journal entry explained, it was due to the elimination technique that I unconsciously used in teaching them how to transfer information effectively from the worksheet to their writing of recounts.

Therefore, it is appropriate to claim that the Dictocomp technique was effective in improving the participants writing of recounts in relation to the text structure. 
INTERNATIONAL JOURNAL OF ACADEMIC RESEARCH IN BUSINESS AND SOCIAL SCIENCES Vol. 10, No. 6, June, 2020, E-ISSN: 2222-6990 @ 2020 HRMARS

\section{Research Question 2}

The test scores obtained when the participants' answers in Test 1 and Test 2 were marked in relation to logical connection of ideas, are presented in Table 2.

Table 2: Participants' results in Test 1 and Test 2 for logical connection of ideas

\begin{tabular}{cccc}
\hline Participant & \multicolumn{3}{c}{ Logical Connection of Ideas } \\
\cline { 2 - 4 } & Test 1 & Test 2 & Difference \\
\hline 1 & 80 & 90 & 10 \\
\hline 2 & 70 & 80 & 10 \\
\hline 3 & 65 & 85 & 20 \\
\hline 4 & 80 & 85 & 5 \\
\hline 5 & 85 & 95 & 10 \\
\hline 6 & 75 & 90 & 15 \\
\hline Mean & 75.8 & 87.5 & 11.7 \\
\hline
\end{tabular}

Table 2 shows that the mean for Test 1 and Test 2 are 75.8 and 87.5 respectively. A comparison in mean scores of both test shows that the mean score of Test 2 were higher by 11.7 percent compared to Test 1 . This indicates that the performance of the participants, in relation to their logical connection of ideas, were generally better in Test 2 as compared to Test 1 . This is also indicated by a significant improvement in percentage of participants who score an $A$ in terms of logical connection of ideas in their answers in Test 1; 50\% to $100 \%$ in Test 2.

The improvement of text structure in the participants' responses has also led to a parallel improvement in logical connection of ideas as indicated by the comparison of the participants' results in terms of text structure and logical connection of ideas as presented in Table 3.

Table 3: Comparison of participants results in the text structure and logical connection of ideas construct

\begin{tabular}{ccccccc}
\hline Participant & \multicolumn{3}{c}{ Text Structure } & \multicolumn{2}{c}{ Logical Connection of Ideas } \\
\cline { 2 - 7 } & Test 1 & Test 2 & Difference & Test 1 & Test 2 & Difference \\
\hline 1 & 80 & 85 & 5 & 80 & 90 & 10 \\
\hline 2 & 70 & 85 & 15 & 70 & 80 & 10 \\
\hline 3 & 65 & 85 & 20 & 65 & 85 & 20 \\
\hline 4 & 80 & 90 & 10 & 80 & 85 & 5 \\
\hline 5 & 80 & 90 & 10 & 85 & 95 & 10 \\
\hline 6 & 80 & 90 & 5 & 75 & 90 & 15 \\
\hline Mean & 75.8 & 87.5 & 11.7 & 75.8 & 87.5 & 11.7 \\
\hline
\end{tabular}

A comparison of the participants' results indicated that an increase in mean in the participants' performance of text structure from 75.8 to 87.5 percent, has also increased accordingly for the participants' performance in logical connection of ideas, which is from 75.8 percent to 87.5 percent. As a result, the difference in mean for both of the constructs in Test 1 and Test 2 is also similar which is 11.7 percent. 
In analyzing the individual results of the participants, it can be seen that the improvement in text structure has also led to the improvement in logical connection of ideas in their recount. This improvement can be seen in the performance of all the participants as indicated in Table 3. Generally, the improvement between 5-10 marks in text structure has also led to an improvement in between 5-10 marks in logical connection of ideas.

An analysis of Participant 3's responses in Test 1 and Test 2 indicated a significant parallel improvement from 65 to 85 percent for both text structure and logical connection of ideas. He demonstrated almost similar level of compliance on the climactic text structure in both tests. This, in particular, is noted with the compliance on 4 Wh-questions: "When", "Who", "Why" and "What", in Test 1 and "When", "Who", Where" and "What", in Test 2. However, he misinterpreted the question and wrote a story instead of a recount in Test 1 . This caused the climactic text structure not to surface strongly in his answer.

However, as he answered the question accordingly in Test 2, the structure, although constituting only the answer of 4 Wh-questions, was significantly better. Accordingly, an introduction, body and conclusion in his recount could be identified more easily. As a result, 1) the introduction of the recount led to main idea of writing, 2) information on events were connected to one another and expressed fluently and 3) the recount was ended well. This essentially, were the criteria assessed in the logical connection of ideas construct.

Therefore, based on the discussion above, it is evident that text structure has a very close relationship with logical connection of ideas, as was expected in this research. The discussion highlighted that adhering to text structure allows information to be clustered accordingly in their groups; introduction, body and conclusion. This scenario further allows each part of the recount to meaningfully lead to the other which, brings about a better logical connection of ideas.

This study contributed immensely to the English language teaching field. Knowledge on the text structure involved in writing can be a valuable tool in organizing any composition writing as the pupils in this research attempted to write their thoughts and arrange them in a piece of coherent text. Thus, since they understood the principles involved in the organizational structure of their writing, they gained insights as to how ideas are linked to form a coherent recount. The findings from this research is beneficial in the ESL context especially at primary school level, where attention and emphasis, have not been adequately focused on the issue of text structure in writing of recounts.

\section{Reflection}

As I reflect on the overall process of the study, the following strengths were the contributing factors to the success of this research:

1) Reading on related literature review, and

2) Discussion of the literature review with supervisors which led further insights into this study.

However, a notable area can be improved in future is that by carrying out the intervention lessons intermittently than consecutively with the participants.

\section{Recommendation}

This study suggests emphasis on some key areas:

1) To investigate if Dictocomp technique can improve other types of text structure in various writing genres. 
INTERNATIONAL JOURNAL OF ACADEMIC RESEARCH IN BUSINESS AND SOCIAL SCIENCES

Vol. 10, No. 6, June, 2020, E-ISSN: 2222-6990 @ 2020 HRMARS

2) Using other techniques that can improve text structure such as direct instruction and comparing its results with the findings of this study, and

3) Replicate this study using the same research design but with different set of ESL learners, for example, of different: a) writing abilities, b) language proficiency levels and c) various learning styles.

\section{References}

Armbuster, B. B., Anderson, T. H., \& Ostertag. (1987). Teaching text structure to improve reading and writing. Reading Teacher, 43, 130-137.

Barnett, M. A. (1989). Foreign language teaching: Theory and practice. New Jersey: Prentice Hall.

Bereiter, C. (1980). Development in writing. New Jersey: Lawrence Earlbaum Publications.

Cali, K., \& Bowen, K. (2014). The five features of effective writing. Retrieved from http://www.learnnc.org/lp/editions/few/683.

Davis, P., \& Rinvolucri, M. (1995). Dictation: New methods new possibilities. Australia: Cambridge University Press.

Dymock, S. (2007). Comprehension strategy instruction: Teaching narrative text structure awareness. Retrieved from https://www.csun.edu/ bashforth/305_PDF/305_Final Proj/TeachingNarrativeStructureAwareness_RT_Oct2007.pdf.

Layne, R., \& Lewis, R. (2009). Plot, theme, the narrative arc, and narrative patterns. Retrieved from http://www.sandhills.edu/academicdepartments/english/film/ narrativearc.html

Mc Gee, L. M., \& Richgels, D. J. (1985). Teaching expository text structures to elementary students. The Reading Teacher, 38, 739-748.

Ministry of education, New Zealand. (2015a). Recounts. Retrieved from http://english online.tki.org.nz/English-Online/Planning-for-my-students-needs/Resources research-andprofessional-support/Features-of-text-forms/Recounts.

Ministry of Education, New Zealand (2015b). Narrative. Retrieved from http://englishonline.tki.org.nz/English-Online/Planning-for-mystudentsneeds/ Resourcesresearch-and-professional-support/Features-of-text-forms/Narrative.

Raimes, A. (1995). Keys for Writers. New York: Wadsworth Publishing.

Stringer, E. (2007). Action research in education. New Jersey: Pearson Education.

Taylor, B. M. (1982). Text structure and children's comprehension and memory from expository material. Journal of Educational Psychology, 74, 323-340. 